\title{
Epidemiological characterization of reported cases of brucellosis in cattle in the western region of the state of Santa Catarina, Brazil
}

\section{Fabricio Bernardi ${ }^{*}$ (i) Marina Gabriela Possa ${ }^{2}$ (i) Mariana Possa ${ }^{3}$ Iucif Abrão Nascif Junior ${ }^{2}$ (D) Camila Elizandra Rossi ${ }^{4}$ (D) Carlos Eduardo Fonseca Alves ${ }^{5,6}$ (i) Fabiana Elias $^{2}$ (D)}

${ }^{1}$ Companhia Integrada de Desenvolvimento Agrícola de Santa Catarina (CIDASC), 89870-000, Pinhalzinho, SC, Brasil. E-mail: bernardi fabricio@hotmail.com. *Corresponding author.

${ }^{2}$ Curso de Medicina Veterinária, Universidade Federal da Fronteira Sul (UFFS), Realeza, PR, Brasil.

${ }^{3}$ Curso de Engenharia Ambiental e Sanitária, Universidade Federal da Fronteira Sul (UFFS), Chapecó, SC, Brasil.

${ }^{4}$ Curso de Nutrição, Universidade Federal da Fronteira Sul (UFFS), Realeza, PR, Brasil.

${ }^{5}$ Instituto de Ciências da Saúde, Universidade Paulista (UNIP), Bauru, SP, Brasil.

${ }^{6}$ Departamento de Cirurgia e Anestesiologia Veterinária, Universidade Estadual Paulista (UNESP), Botucatu, SP, Brasil.

ABSTRACT: Brucellosis is one of the most important and widespread bacterial zoonoses in the world. There are few epidemiological studies on brucellosis in cattle in the productive region of western Santa Catarina. Thus, the objective of this study was to characterize the epidemiological aspects of bovine brucellosis reported in this region from 2013 to 2018. Cattle data were provided by the Integrated Company for Agricultural Development of Santa Catarina (Companhia Integrada de Desenvolvimento Agrícola de Santa Catarina - CIDASC). The prevalence of the disease was evaluated in cattle and herds by means of temporal trend analysis and spatial distribution. Bovines with tests showing positive for brucellosis were analyzed for location (municipality) and year of confirmation of diagnosis. In the study period (20132018), 686,086 tests were performed for brucellosis, with a prevalence rate of 1.11\% (7,586/686,086). Among the 80,171 herds tested, $0.95 \%$ were found to be positive (764/80171). The odds ratio of brucellosis occurrence in cattle increased significantly in $2015(O R=1.55)$ and 2016 $(O R=1.97)$ and decreased in $2014(O R=0.47)$ and $2017(O R=0.97)$. The disease is present in cattle in $61.07 \%(80 / 131)$ of the municipalities where the tests were performed. Results showed that brucellosis is endemic in the region.

Key words: zoonosis, serology, prevalence.

Caracterização epidemiológica dos casos notificados de brucelose em bovinos na região Oeste do Estado de Santa Catarina, Brasil

RESUMO: A brucelose é uma das zoonoses bacterianas mais importantes e difundidas no mundo. São poucos os estudos epidemiológicos sobre a doença em bovinos na região produtiva do Oeste de Santa Catarina. Desta forma, o objetivo deste estudo foi caracterizar os aspectos epidemiológicos da brucelose bovina notificados nesta região entre os anos de 2013 a 2018. Os dados sobre os bovinos foram fornecidos pela Companhia Integrada de Desenvolvimento Agrícola de Santa Catarina (CIDASC). Foram avaliadas as prevalências da doença nos bovinos e rebanhos, por meio de análise de tendência temporal e distribuição espacial. Os bovinos, cujo exame confirmatório mostrou positividade para brucelose, foram analisados quanto à localização (município) e o ano de confirmação do diagnóstico. No periodo de estudo (2013-2018) foram realizados 686.086 testes para brucelose, encontrando-se prevalência de 1,11\% (7.586/686.086) de animais positivos, enquanto a prevalência de rebanhos positivos, dentre os 80.171 testados, foi de 0,95\% (764/80171). As razões de chances de ocorrência de brucelose nos bovinos aumentaram significativamente nos anos de $2015(O R=1,55)$ e $2016(O R=1,97)$ e diminuiram em $2014(O R=0,47)$ e $2017(O R=$ 0,97). A doença está presente nos bovinos em 61,07\% (80/131) dos municipios em que foram realizados os testes. Os resultados demonstram que a brucelose é endêmica na região.

Palavras-chave: zoonose, sorologia, prevalência.

\section{INTRODUCTION}

The state of Santa Catarina, located in the southern region of Brazil, corresponds to $1.12 \%$ of the national territory. Despite this small land area, the state stands out in livestock production (IBGE, 2017) as the fifth largest producer of milk. Regarding animal health, the state has sanitary regulations and has been recognized internationally as being free of foot-and-mouth disease without vaccination since 2007 (OIE, 2019).

Despite the different sanitary regulations in the state, cattle production continues, and advances 
in cattle health with disease surveillance are required. Brucellosis is one of the most important and widespread bacterial zoonoses in the world (ZHANG et al., 2018; CÁRDENAS et al., 2019). The disease is caused by bacteria of the genus Brucella, with $B$. abortus being the most prevalent species in the country (CORBEL, 2006).

To reduce the negative impact of brucellosis and tuberculosis on productivity in human and animal health and to promote the competitiveness of national livestock production, the National Program for the Control and Eradication of Brucellosis and Animal Tuberculosis (Programa Nacional de Controle and Erradicação da Brucelose e da Tuberculose Animal - PNCEBT) was created in 2001 by the Ministry of Livestock and Food Supply (Ministério da Agricultura Pecuária and Abastecimento - MAPA) (BRASIL, 2006). Since then, several Brazilian states have conducted studies on the prevalence of brucellosis in cattle. The sample surveys showed that the disease is endemic in Brazil, with a heterogeneous prevalence among the states. The lowest prevalence rate was observed in Santa Catarina (BAUMGARTEN et al., 2016). After the adoption of eradication measures in the state of Santa Catarina in 2012 (SANTA CATARINA, 2012), no epidemiological surveys were conducted.

The present study was developed with the objective of characterizing the epidemiology of bovine brucellosis in 131 municipalities in the western region of the state of Santa Catarina from January 2013 to December 2018.

\section{MATERIALS AND METHODS}

\section{Selecting the geographic region}

Santa Catarina is divided into five productive regions according to Sikusawa et al. (2009) (Figure 1). In this study, bovine brucellosis data from the 131 municipalities that make up productive region 3 - western Santa Catarina - were analyzed. This region was selected because it is the main dairy production region and has the most cattle in Santa Catarina. Additionally, this region was selected due the proximity of the border with the states of Rio Grande do Sul and Paraná and the international border with Argentina.

\section{Data collection and inclusion criteria}

Information on bovine brucellosis was obtained from the Integrated Company for Agricultural Development of Santa Catarina (Companhia Integrada de Desenvolvimento Agrícola de Santa Catarina - CIDASC). The study period was from January 2013 to December 2018. The available information included year/month of the test; municipality; number of farms with examined

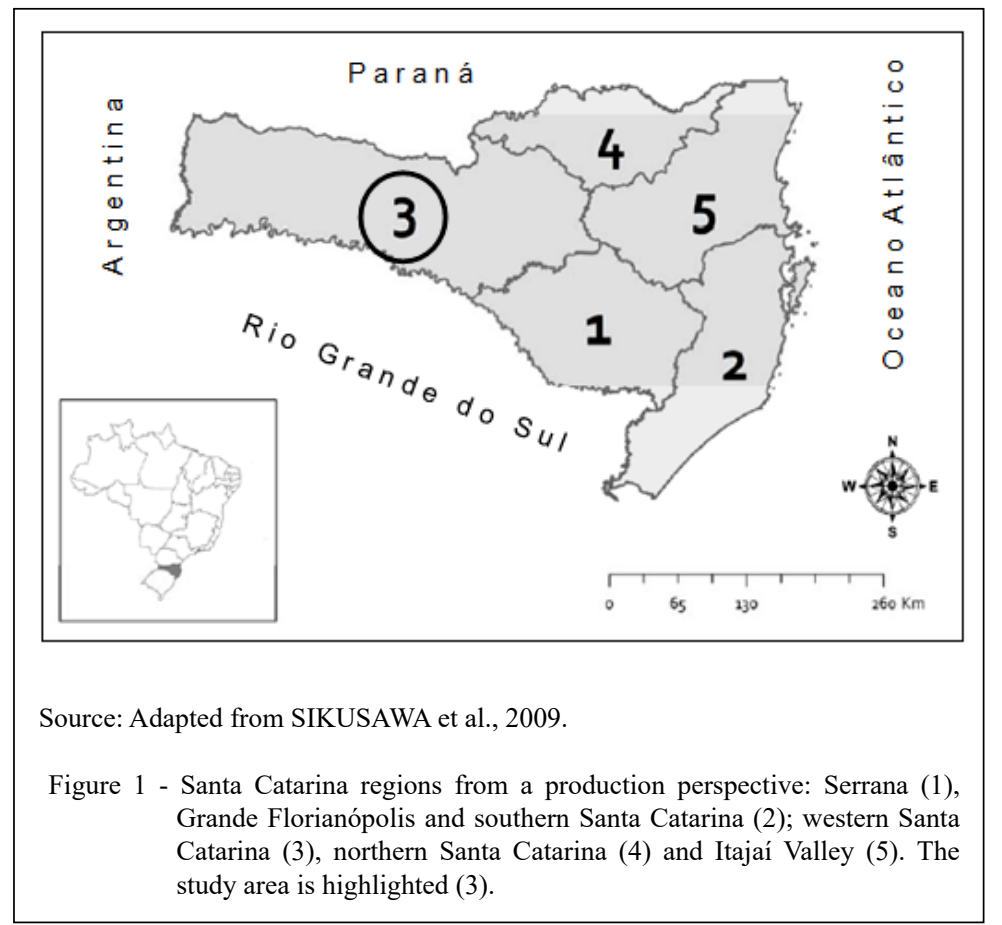

Ciência Rural, v.50, n.8, 2020. 
animals; number of animals examined (for the triage and confirmatory tests); number of positive animals in the confirmatory test; and number of establishments with positive animals. Monthly data were collected on the total cattle and the total number of farms with cattle in each municipality of the study using the Santa Catarina Agricultural Defense Management System (Sistema de Gestão da Defesa Agropecuária Catarinense - SIGEN+).

The analyzed data were collected from bovines that had their serum tested for brucellosis by trained veterinarians from the private sector and the Official Veterinary Service (Serviço Veterinário Oficial - SVO). These animals included both males intended for breeding and females, aged eight months or older (BRASIL, 2017), as vaccination of the animals with the B-19 vaccine is not practiced in the state of Santa Catarina. The animals were examined according to the demand of the producers, and some animals and herds were examined more than once during the study period.

A positive case was defined as any animal that had a conclusive positive diagnosis in the 2-mercaptoethanol (2-ME) confirmatory test or fluorescent polarization assay (FPA) performed by an official and/or accredited laboratory, after a reactive result from the buffered acidified plate antigen screening test or two consecutive inconclusive results from the confirmatory test (BRASIL, 2017). Each animal was considered a case only once because positive animals are referred for sanitary sacrifice within 30 days of diagnosis (SANTA CATARINA, 2012; BRAZIL, 2017).

Facilities that had at least one bovine positive for brucellosis were considered focus properties (BRASIL, 2017). The foci of the disease were counted from the "Informes Epidemiológicos Estaduais/GEDSA" ("State Epidemiological Reports/ GEDSA) provided by CIDASC and refers to the occurrences reported each month (CIDASC, 2018).

\section{Data analysis}

The annual prevalence of brucellosis and the total bovine-positive period were calculated for the foci according to PEREIRA (2008). The total distribution of cases was verified each month during the study period.

A temporal trend analysis was performed with logistic regression on data from cattle examined for brucellosis to understand associations between the prevalence of cases per year. We performed univariate logistic regression analysis and odds ratio estimates with $95 \%$ confidence intervals using Stata software version $13.0^{\circledR}$. Spatial analysis was performed by developing thematic maps showing the distribution in municipalities with positive bovines in absolute number of cases. The maps were elaborated using QGIS free software version 3.4.8 (Las Palmas de G.C.).

\section{RESULTS AND DISCUSSION}

Data from 686,086 samples of bovine sera from 80,171 herds of the 131 municipalities of the western region of Santa Catarina were analyzed. Of the total number of tests performed, 7,586 cattle had a positive diagnosis using the confirmatory test for brucellosis (2-ME), and these were distributed in 764 herds (Table 1).

The low prevalence in herds and in cattle corroborates the results found by other authors in the same region and state (BRASIL, 2006; SIKUSAWA et al., 2009; BAUMGARTEN et al., 2016). These data demonstrated that brucellosis rates are stable but low in Santa Catarina's western region, despite an approximately $11 \%$ increase in the cattle herd, when comparing the average of the six years in the study (CIDASC, 2019) with the actual value for 2012.

In a survey conducted in 2001, Sikusawa et al. (2009) estimated a state average of $0.32 \%$ in herds and $0.06 \%$ in cattle. They did not observe cases of brucellosis in the western region, but estimated the prevalence in herds to be $0.25 \%$. In contrast, in

Table 1 - Number and prevalence of herds and cattle examined for bovine brucellosis in the western region of Santa Catarina from 2013 to 2018.

\begin{tabular}{|c|c|c|c|c|c|c|}
\hline & \multicolumn{3}{|c|}{-----------------------------HERDS--------------------------- } & \multicolumn{3}{|c|}{ 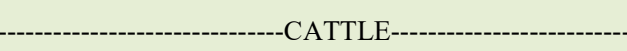 } \\
\hline Results & No. ${ }^{1}$ & Prevalence & $95 \% \mathrm{CI}$ & No. ${ }^{2}$ & Prevalence & $95 \% \mathrm{CI}$ \\
\hline Negative & 79.407 & $99.05 \%$ & $98.98-99.11$ & 678.500 & $98.89 \%$ & $98.87-98.92$ \\
\hline Positive & 764 & $0.95 \%$ & $0.89-1.02$ & 7.586 & $1.11 \%$ & $1.08-1.13$ \\
\hline Total & 80.171 & $100 \%$ & & 686.086 & $100 \%$ & \\
\hline
\end{tabular}

${ }^{1}$ Number of herds. ${ }^{2}$ Number of cattle. ${ }^{*} \mathrm{CI}$ : Confidence interval. 
a study conducted in 2012, Baumgarten et al. (2016) estimated the mean prevalence in the state to be $0.91 \%$ in herds and $1.21 \%$ in animals. Additionally, they estimated a prevalence of $1.09 \%$ in herds and $1.97 \%$ in cattle in the western region. The prevalence observed by Baumgarten et al. (2016) in the western region was slightly higher than that $(0.95 \%$ in herds and $1.11 \%$ in animals) observed for the region in the present study, revealing the manifestation of the disease in the study period.

The increase in the prevalence rates of bovine brucellosis observed between the studies from 2001 and 2012 led to the implementation of the State Program for the Eradication of Brucellosis and Tuberculosis (Programa Estadual de Erradicação da Brucelose e Tuberculose - PEEBT) in Santa Catarina (SANTA CATARINA, 2012). The 2012 survey was crucial to establish the resources to be used to control and eliminate the disease in the state. Afterwards, herd examinations were performed to control the outbreak to identify all positive animals from the same herd (SANTA CATARINA, 2012; BAUMGARTEN et al., 2016).

Results reported in this study reinforced the observation that Santa Catarina has the lowest occurrence of brucellosis in the country. The states closest to Santa Catarina with herd and cattle brucellosis prevalences included Rio Grande do Sul, with 3.54\% and $0.98 \%$, respectively (SILVA et al., 2016);
Minas Gerais, with $3.59 \%$ and $0.81 \%$, respectively (OLIVEIRA et al., 2016); and Paraná, with $4.0 \%$ and $1.7 \%$, respectively (DIAS et al., 2009). Heterogeneous distribution of the disease in Brazil reinforced the need to establish independent state programs for control and eradication according to the prevalence in each state. For prevalence rates $\leq 2 \%$, the adopted strategy must be eradication by testing cattle and then sacrificing positive animals (CORBEL, 2006), which was previously adopted in the state.

The high prevalence in animals compared to herds in the western region (when compared to the other four production circuits in the state (SIKUSAWA et al., 2009; BAUMGARTEN et al., 2016)) is possibly because most of the state herds are reported in this region, which has a predominance of dairy cattle farming. Additionally, livestock farming occurs in intensive or semi-intensive systems, where transmission between animals is facilitated. Greater numbers of animals are confined together, favoring the spread of the disease after the birth of a positive bovine with other animals of the herd due to the natural habit of the animals (SANTOS et al. 2007). Another factor that contributed to this phenomenon in the western region is that this region has the highest concentration of veterinarians qualified in the PNCEBT (CIDASC, 2019), resulting in a larger number of tests. Figure 2 shows the distribution of

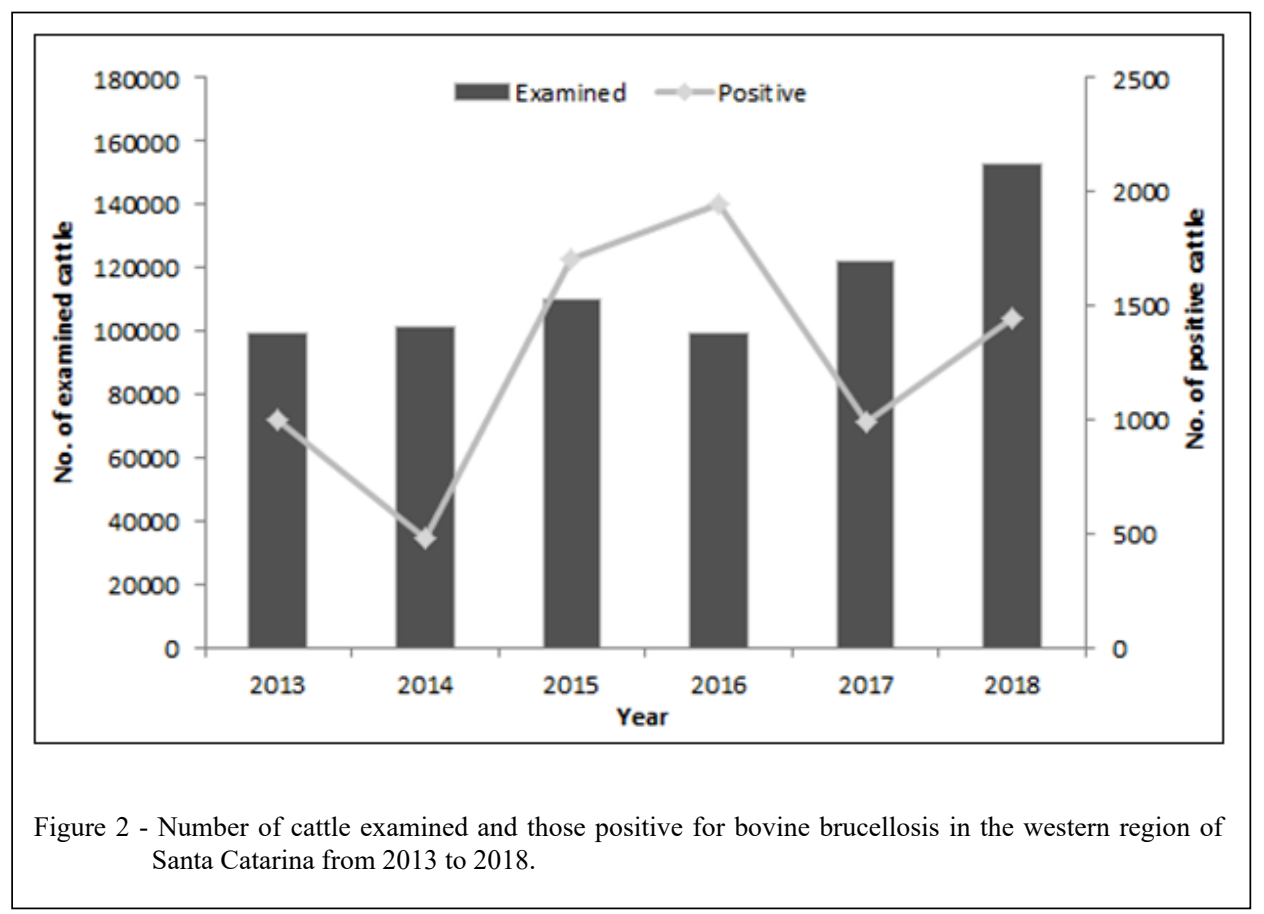

Ciência Rural, v.50, n.8, 2020. 
the number of tested samples and positive animals between 2013 and 2018.

Table 2 shows that there was an annual increase in the absolute and relative number of tests performed, with the exception of 2016. The smallest number of examinations performed in 2016 occurred due to the interruption of the supply of raw materials for the diagnosis of bovine brucellosis by the main manufacturer laboratory in the country. From August to September 2016, 4,035 samples of tank milk were analyzed by enzyme-linked immunosorbent assay (ELISA) from different herds. These samples were tested by the Brazilian Milk Quality Network laboratory (Rede Brasileira de Qualidade do Leite RBQL), and of these, 102 (2.53\%) were reactive for brucellosis (BAUMGARTEN et al., 2017), resulting in a higher number of positive cattle in 2016 (although, not all of the farms have been confirmed as foci).

The National System of Animal Health Information (Sistema Nacional de Informação Zoosanitária - SIZ) provided the total number of reported cases of brucellosis. In the state of Santa Catarina, there were 8,520 cattle cases reported between 2013 and 2018 (SIZ, 2019). In the western region of Santa Catarina, there were 7,586 cases, which represented $89.04 \%$ of the total cases of bovine brucellosis within the period. These data suggested that in the remainder of the state, brucellosis has a lower prevalence (SIKUSAWA et al., 2009; BAUMGARTEN et al., 2016) and possibly lower testing rates (BAUMGARTEN et al., 2016).

Additionally, in the western region, the Brucellosis Eradication pilot project was implemented in June 2014 with the milk ring screening test (MRT), followed by the ELISA test and individual serology of the bovines, which allowed for the identification of foci and positive animals (CIDASC, 2019).
The observed decrease in prevalence from 2013 to 2014 was significant, as the odds ratios decreased from 1.00 (reference value) to 0.47 (OR: $0.47 ; \mathrm{P}=0.000$ and CI: $0,42-0.52$ ). The observed increase from 2014 to 2015 and then in 2016 was also significant $(2015=$ OR: $1.55 ; \mathrm{P}=0.000$ and CI: $1.43-1.68$ and 2016 $=$ OR: $1.97 ; \mathrm{P}=0.000$ and CI: $1.83-2.13)$. In 2017, the odds ratio was reversed, indicating a significant decrease in the number of brucellosis cases from 2016 to 2017 (OR: $0.80 ; \mathrm{P}=0.000$ and $\mathrm{CI}: 0.73-0.88)$. This increase in individual cattle presenting a positive diagnosis in 2015 and 2016 was possibly due to the pilot project and the diagnosis of brucellosis in milk, starting June 2014 (CIDASC, 2019). Between 2017 and 2018, the odds ratio for the occurrence of brucellosis in each animal was statistically similar to that of 2017 (Table 2).

As shown in figure 3, the year with the greatest number of both tested herds and outbreaks in herds was 2013. Until June 2014, both new and old foci were added to the monthly epidemiological reports (CIDASC, 2019). It is possible that the overlap of new and old foci may have contributed to the high number of positive herds in 2013.

In the SIZ database, 917 outbreaks were reported throughout the state between 2013 and 2018 (SIZ, 2019). In the same period, 764 foci were recorded in the western region, representing $83.32 \%$ of the total for the state, demonstrating that the region had the highest number of herds and cattle diagnosed with infection.

In addition to the concentration of livestock and veterinarians qualified in the PNCEBT, western Santa Catarina contains the majority (351/377 $(93.10 \%))$ of certified properties free of brucellosis and tuberculosis in the state. This is likely due to free adherence of producers (CIDASC, 2019), which increases the chances of identifying positive herds.

Table 2 - Number, percentage and logistic regression of examined and positive cattle for brucellosis per year in the western region of Santa Catarina from 2013 to 2018.

\begin{tabular}{lccccccr}
\hline Year & Examined & $\%$ & Positive & $\%$ & OR $^{1}$ & $\mathrm{P}^{2}$ & $95 \% \mathrm{CI}^{3}$ \\
\hline 2013 & 99,729 & 14.54 & 1,001 & 13.20 & 1 & 0.47 & $0.000^{\mathrm{a}}$ \\
2014 & 101,798 & 14.84 & 485 & 6.39 & $0.42-0.52^{\mathrm{a}}$ \\
2015 & 110,152 & 16.06 & 1,710 & 22.54 & 1.55 & $0.000^{\mathrm{a}}$ & $1.43-1.68^{\mathrm{a}}$ \\
2016 & 99,372 & 14.48 & 1,952 & 25.73 & 1.97 & $0.000^{\mathrm{a}}$ & $1.83-2.13^{\mathrm{a}}$ \\
2017 & 122,420 & 17.84 & 992 & 13.08 & 0.80 & $0.000^{\mathrm{a}}$ & $0.73-0.88^{\mathrm{a}}$ \\
2018 & 152,615 & 22.24 & 1,446 & 19.06 & 0.94 & 0.159 & $0.87-1.02$ \\
\hline Total & 686,086 & 100 & 7,586 & 100 & & & \\
\hline
\end{tabular}

1- OR: odds ratio; 2 - P-value; 3 - CI: 95\% confidence interval; a: $\mathrm{p}<0.05$. 


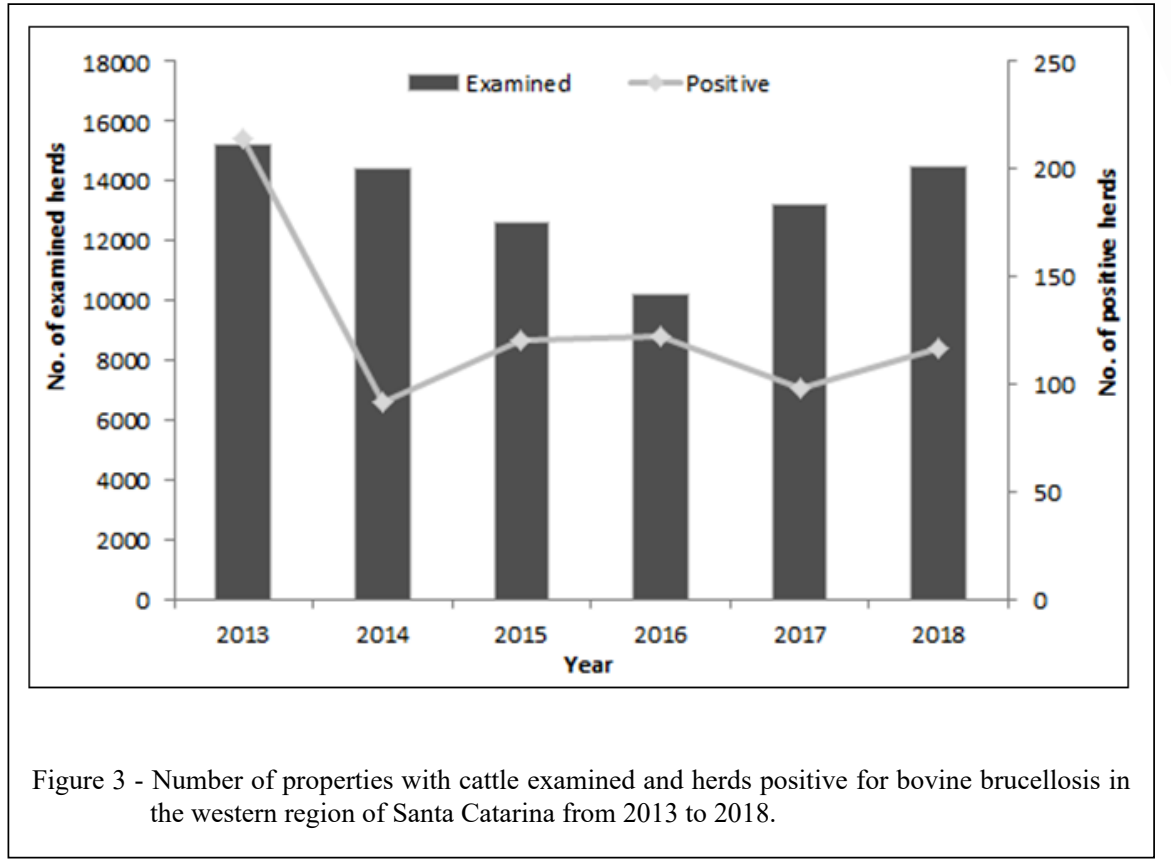

The spatial distribution of bovine herds in absolute numbers can be observed in figure 4. A high spatial distribution of infection in the region was observed in $61.07 \%(80 / 131)$ of the municipalities during the study period. There was a higher concentration of foci from the midwest to the far west. The borders of northern Rio Grande do Sul and southwestern Paraná had a higher number of cattle and foci compared to the border with Argentina.

However, the epidemiological situation is unknown at the Argentinean border, as no serological studies were conducted due to the low concentration of cattle herds (SENASA, 2014). The prevalence was $1 \%$ for herds and $2.2 \%$ for animals in southwestern Paraná (DIAS et al., 2009) and 2.58\% for herds and $0.40 \%$ for animals in the northern region of Rio Grande do Sul (SILVA et al., 2016).

The entry of cattle from Rio Grande do Sul and Paraná to Santa Catarina is prohibited due to the different sanitary regulations for foot-andmouth disease. Therefore, transmission by direct contact does not occur legally due to the existence

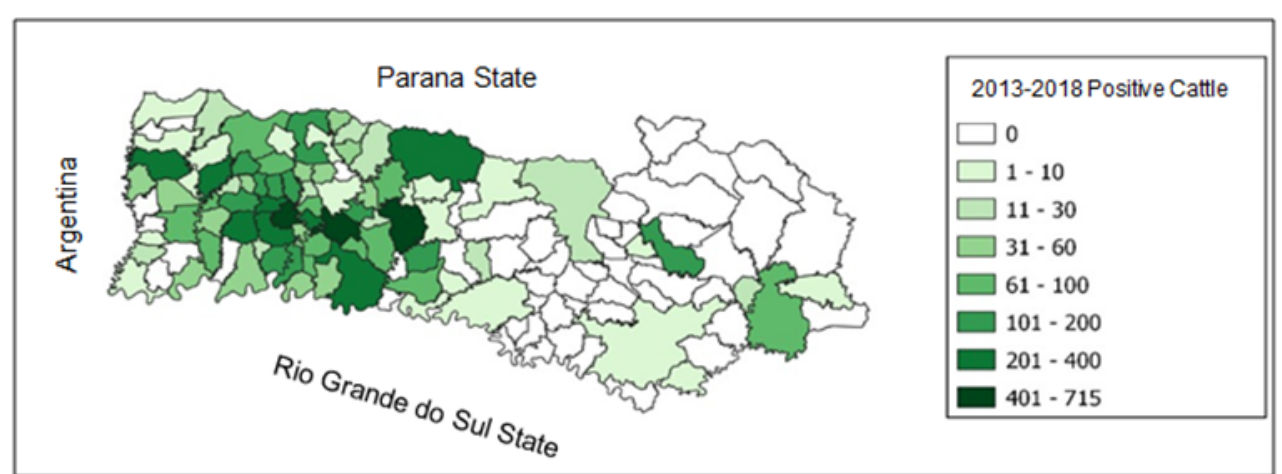

Figure 4 - Spatial distribution of positive bovine cases of brucellosis in absolute numbers in the western region of Santa Catarina from 2013 to 2018. 
of barriers and three sanitary corridors (CIDASC, 2019). It is believed that brucellosis can be present in wild and/or feral animals such as hares, cervids and wild boars, which can act as reservoirs (CROSS et al., 2010). Equines that are transiting in the border regions may also have the disease and contribute to the maintenance of brucellosis in bovines, which are the preferred hosts of Brucella abortus (CORBEL, 2006).

Throughout the study period, the total number of positives cases ranged from 487 cases in March to 1,131 cases in November (January: 522; February: 610; March: 487; April: 603; May: 513; June: 618; July: 667; August: 517; September: 490; October: 800; November: 1,131 and December: 628). The largest number of cases in November was due to the detection of a large number of animals in a single outbreak.

Even with the adoption of active surveillance for brucellosis and an increase in the bovine population, there was no increase in the percentage of outbreaks and positive animals between January 2013 and December 2018 compared to the previous study. Knowledge of the prevalence of a disease is essential to evaluate the efficacy of an eradication program (ZHANG et al., 2018), demonstrating that the state is on the path to eradicate the disease in cattle.

The limitations of the study include the use of secondary data, possible failures in the compilation of data from the received and original spreadsheets and the fact that the original spreadsheets were filled by the Local Veterinary Units, then transferred to the Regional Departments and later to the CIDASC Central Department.

\section{CONCLUSION}

Results indicated that brucellosis is an endemic disease in Santa Catarina, with low prevalence in herds and cattle, and is distributed in more than half of the municipalities in the western region. Moreover, the results suggested that the state of Santa Catarina should continue concentrating its efforts on strategies to eradicate the disease.

\section{ACKNOWLEDGEMENTS}

We would like to acknowledge to CIDASC. This study was financed in part by the Coordenação de Aperfeiçoamento de Pessoal de Nível Superior - Brasil (CAPES) - Finance Code 001.

\section{DECLARATION OF CONFLICT OF INTERESTS}

The authors declare no conflict of interest. The founding sponsors had no role in the design of the study; in the collection, analyses, or interpretation of data; in the writing of the manuscript, and in the decision to publish the results.

\section{AUTHORS' CONTRIBUTIONS}

All authors contributed equally to the drafting and writing of the manuscript. All authors reviewed the manuscript and approved the final version.

\section{REFERENCES}

BAUMGARTEN, K. D. et al. Prevalence and risk factors for bovine brucellosis in the State of Santa Catarina, Brazil. Semina: Ciências Agrárias. v.37, n.5, p.3425-3436, 2016. Available from: $<$ http://www.uel.br/revistas/uel/index.php/ semagrarias/article/view/27216>. Accessed: Aug. 27, 2019. doi: 10.5433/1679-0359.2016v37n5Supl2p3425.

BAUMGARTEN, K. D. et al. A vigilância ativa da brucelose com o apoio da indústria leiteira e da rede brasileira de laboratórios de controle da qualidade do leite [Active surveillance of brucellosis with the support of the dairy industry and the Brazilian network of milk quality control laboratories]. In: V ENCONTRO NACIONAL DE DEFESA SANITÁRIA ANIMAL, ENDESA 2017 [V NATIONAL MEETING ON ANIMAL HEALTH DEFENSE, ENDESA 2017]. 2017. Anais... Serviço Veterinário Brasileiro: em busca da sustentabilidade [Brazilian Veterinary Service: in search of sustainability]. O Biológico, São Paulo, v.79, n.2, p.9-97, Jul./ Dec. Portuguese.

BRASIL, Ministério da Agricultura Pecuária e Abastecimento. Instrução Normativa SDA No 30, de 07 de junho de 2006 [Normative Instruction SDA $\mathrm{N}^{0}$ 30, from June 7, 2006]. Diário Oficial da União (DOU). Brasília, p.5, section 1, ed. 114. June 16, 2006. Portuguese.

BRASIL, Ministério da Agricultura Pecuária e Abastecimento Instrução Normativa SDA N 10 , de 03 de março de 2017 [Normative Instruction SDA N ${ }^{\circ} 10$, from March 3, 2017]. Diário Oficial da União (DOU). Brasília, p.4, section 1, ed. 116. June 20, 2017. Portuguese.

CÁRDENAS, L. et al. Characterization and evolution of countries affected by bovine brucellosis (1996-2014). Transboundary and Emerging Diseases. p.1-11, 2019. Available from: $<$ https://www. ncbi.nlm.nih.gov/pubmed/30739391>. Accessed: Aug. 27, 2019. doi: $10.1111 /$ tbed.13144.

CIDASC, Companhia Integrada de Desenvolvimento Agrícola de Santa Catarina. Serviço - Defesa Sanitária Animal: Informes epidemiológicos [Service - Animal Sanitary Defense: Epidemiological reports]. 2018. Available from: $<$ http://www.cidasc.sc.gov.br/defesasanitariaanimal/informesepidemiologicos/>. Accessed: Apr. 28, 2019. Portuguese.

CIDASC, Companhia Integrada de Desenvolvimento Agrícola de Santa Catarina. Estado de Santa Catarina [State of Santa Catarina]. 2019. Available from: <http://www.cidasc.sc.gov.br>. Accessed: May, 23, 2019. Portuguese.

CORBEL, M. J, Food and Agriculture Organization of the United Nations, World Health Organization \& World Organisation for Animal Health. (2006). Brucellosis in humans and animals. World Health Organization. Accessed: Apr. 30, 2019. Available from: $<\mathrm{http}$ :/ www.who.int/iris/handle/10665/43597>. Accessed: May, 23, 2019. 
CROSS, P., et al. Probable causes of increasing brucellosis in freeranging elk of the Greater Yellowstone Ecosystem. Ecological Application. v.20, p.278-288, 2010. Available from: <https:// www.ncbi.nlm.nih.gov/pubmed/20349847>. Accessed: Oct. 21, 2019. doi: 10.1890/08-2062.1

DIAS, J. A. et al. Epidemiological situation of bovine brucellosis in the State of Paraná, Brazil. Arquivo Brasileiro de Medicina Veterinária e Zootecnia, Belo Horizonte, v.61, p.66-76, 2009. Available from: $<\mathrm{http}$ //dx.doi.org/10.1590/S010209352009000700009>. Accessed: Aug. 27, 2019.

IBGE, Instituto Brasileiro de Geografia e Estatística. Censo Agropecuário [Agricultural Census]. 2017. Available from: $<$ https://cidades.ibge.gov.br/brasil/pesquisa/24/76693>. Accessed: May, 23, 2019. Portuguese.

OIE, World Organisation For Animal Health. List of FMD free members countries - according to resolution $\mathbf{n}^{\circ} \mathbf{1 5}-87$ th General Session May 2019. Paris: OIE, 2019. 4p.

OLIVEIRA, L. F. et al. Seroprevalence and risk factors for bovine brucellosis in the State of Minas Gerais, Brazil. Semina: Ciências Agrárias. v.37, n.5, p.3449-3446, 2016. Available from: <http://www.uel.br/revistas/uel/index.php/ semagrarias/article/view/27226>. Accessed: Aug. 27, 2019. doi: 10.5433/1679-0359.2016v37n5Sup12p3449.

PEREIRA, M.G. Epidemiologia: teoria e prática [Epidemiology: theory and practice]. 12. ed. Rio de Janeiro: Guanabara Koogan, 2008. 596p. Portuguese.

SANTA CATARINA (Estado). Secretaria de Estado da Agricultura e da Pesca. Portaria SAR no 17/2012 [SAR Ordinance No. 17/2012], from 20/07/2012. Diário Oficial do Estado de Santa Catarina. Florianópolis, SC, July 24, 2012. ed. 19.380, p.3. Portuguese.

SANTOS, H. P. et al. Brucelose bovina e humana diagnosticada em matadouro municipal de São Luís - MA, Brasil [Bovine and human brucellosis diagnosed in a county slaughterhouse in São Luís - MA,
Brazil]. Ciência Veterinária Trópica. v.10, n.2/3, p.86-94, 2007. Available from: <http://www.rcvt.org.br/volume10_2_3/86-94. pdf $>$. Accessed: Aug. 27, 2019. Portuguese.

SENASA, Servicio Nacional de Sanidad Y Calidad Agroalimentaria. Informe del muestreo para determinación de prevalencias de brucelosis bovina en la zona de mayor producción bovina en la Republica Argentina Año 2014 [Sampling report for the determination of bovine brucellosis prevalence in the area with the highest bovine production in the Argentine Republic, Year 2014]. Buenos Aires. Available from: <https://www.argentina.gob.ar/ sites/default/files/15_d-informe_final_muestreo_brucel osis_bovina_ ano_2014_10-12-15.pdf>. Accessed: May, 31, 2019. Spanish.

SIKUSAWA, S. et al. Situação epidemiológica da brucelose bovina no Estado de Santa Catarina [Epidemiological situation of bovine brucellosis in the State of Santa Catarina, Brazil]. Arquivo Brasileiro de Medicina Veterinária e Zootecnia. v.61, p.103-108, 2009. Available from: <http://www.scielo.br/ scielo.php?script $=$ sci_arttext\&pid $=$ S0102-09352009000700013 $>$. Accessed: Aug. 27, 2019. Portuguese.

SILVA, N. S. et al. Epidemiological situation of brucellosis after implementation of the vaccination program in Rio Grande do Sul State, Brazil. Semina: Ciências Agrárias. v.37, n.5, p.3519-3530, 2016. Available from: <http://www.uel.br/revistas/uel/index.php/ semagrarias/article/view/27238>. Accessed: Aug. 27, 2019. doi: 10.5433/1679-0359.2016v37n5Sup12p3519.

SIZ, Sistema de Informação Zoossanitária. Dados Zoossanitários [Animal Health Data]. Coordenação de Informação e Epidemiologia - Saúde Animal, MAPA, 2019. Available from: $<$ http://indicadores.agricultura.gov.br/saudeanimal/index.htm $>$. Accessed: Aug. 07, 2019. Portuguese.

ZHANG, N. Z. et al. Animal brucellosis control or eradication programs worldwide: a systematic review of experiences and lessons learned. Preventive. Veterinary Medicine. v.160, 2018. Available from: <https://doi.org/10.1016/j.prevetmed.2018.10.002>. Accessed: Aug. 27, 2019. 